\title{
Pros and cons of innovations in medical education
}

Alberto Lifshitz-Guinzberg, ${ }^{1,2 *}$ Luis F. Abreu-Hernández, ${ }^{1,3}$ Ana C. Sepúlveda-Vildósola, ${ }^{1,4}$ Ma. Esther Urrutia-Aguilar, ${ }^{1,5}$ José Á. Córdova-Villalobos, ${ }^{1,6}$ Joaquín López-Bárcena ${ }^{1,7}$ and Melchor Sánchez-Mendiola²

${ }^{1}$ Medical Education Committee, Academia Nacional de Medicina; ${ }^{2}$ Faculty of Medicine, Universidad Nacional Autónoma de México; ${ }^{3}$ Postgraduate Education Division, Universidad Nacional Autónoma de México; ${ }^{4}$ Health Research Coordination, Instituto Mexicano del Seguro Social; ${ }^{5}$ Postgraduate Unit, Universidad Nacional Autónoma de México; ${ }^{6}$ Former Secretary of Health of Mexico; ${ }^{7}$ Academia Nacional de Educación Médica. Mexico City, Mexico

\section{Abstract}

Medical education has implemented various innovative strategies with the purpose to attain better learning achievements. An evaluation is made of the experiences in the competencies approach, new learning technologies, curricular alternatives, professional evaluation and distance education technologies in order to locate them in the areas they belong.

KEY WORDS: Education. Learning technology. Competencies. Evaluation. Curriculum.

\section{Pros y contras de las innovaciones en educación médica}

\section{Resumen}

La educación médica ha puesto en práctica diversas estrategias innovadoras con el propósito de alcanzar mejores logros de aprendizaje. Se hace una evaluación de las experiencias relacionadas con el enfoque por competencias, las nuevas tecnologías educativas, las alternativas curriculares, la profesionalización de la evaluación y las técnicas educativas a distancia, para ubicarlas en el lugar que les corresponde.

PALABRAS CLAVE: Educación. Tecnología educativa. Competencias. Evaluación. Currículo.

\section{Introduction}

\section{Alberto Lifshitz}

Innovation and creativity are two values that are highly appreciated by society and are the foundation of progress. Medical education has a commitment with apprentices for achieving higher learning efficiency and, therefore, it is in constant search for better strategies. Current circumstances have led to an acceleration of this search, but a wake-up call is always advisable in the sense that the newest is not necessarily the best, at least not only because it is new. Thus, not only innovations have emerged, but simple novelties, fashions, notions, whims, insubstantial changes or even setbacks that appear to be progressess. For this reason, a critical stance without dazzles is always advisable and, as far as possible, an evaluation of advantages and disadvantages. First impressions are not always reliable and things have to be given time to put them to the test.

Some of the innovations herein mentioned may seem not that new, but now is a good time to subject them to a critical analysis.
Correspondence:

*Alberto Lifshitz-Guinzberg

E-mail: alifshitzg@yahoo.com
Gac Med Mex. 2021;157:325-334 Contents available at PubMed www.gacetamedicademexico.com 0016-3813/C 2021 Academia Nacional de Medicina de México, A.C.. Published by Permanyer. This is an open access article under the CC BY-NC-ND license (http://creativecommons.org/licenses/by-nc-nd/4.0/). 


\section{Competency-based education}

\section{Luis F. Abreu-Hernández}

Competent doctors are those who have the potential to efficiently fulfill the functions demanded to the profession by society; they show their capacity to act in the dynamic and complex environments where medicine is practiced, which implies an articulation of knowledge, cognitive processes and intellectual abilities, skills, values, culture and social relationships, which allow responding to the requirements of present and future professional practice and preserving its quality in a plurality of contexts and situations. They maintain the ability to establish optimal courses of action through constant evolution, teamwork capacity, reflection on actions, scientific knowledge, multidisciplinary management, flexibility, adaptability, results evaluation, social commitment and farsightedness.

Sociologist Eliot Freidson ${ }^{1}$ described medicine as a profession characterized by the exercise of autonomy, where doctors make decisions for solving health problems, based on the body of medical knowledge. In the face of this open and dynamic notion, another of a bureaucratic nature has developed, which tends to limit professional autonomy by applying industrial administration methods. Controlling physicians' actions has been attempted, putting savings and profits before health care and empathy with the patient; turning doctors into instrumental beings that uncritically apply rules, guidelines, protocols and standardized processes has been attempted, under the assumption that all patients are the same and respond the same way. Health care has been transformed into an industrial system that processes individuals in a mechanical, dehumanized way, with priorities unrelated to people's health and that has been characterized as "industrialized medicine". ${ }^{2}$

This polarization has translated into two conflicting definitions of competencies. Barton Childs ${ }^{3}$ has pointed out that medicine cannot be based on the belief that all patients are the same and respond the same way, given that medicine has to recognize genetic variability and social variability, and that each patient is unique. For this reason, the physician must contextualize the knowledge on each specific patient, which has been called "precision medicine". ${ }^{4}$ Strict application of evidence-based medicine leads to error and prevents advances. Donald Berwick, one of the best experts in quality of care, has pointed out that by eliminating the variations we also ignore the context, and has stated that "without evidence we can do harm, but it is also equally harmful to treat a complex phenomenon as if it was simple and when we treat unique people as if they were simple parts separated from us, we reduce our capacity to see, learn, discuss, and grow". ${ }^{5}$

It is convenient to distinguish between the real competency of living and acting medical professionals and competency as a written description, intended to guide the activities of a study plan; the latter is partly obtained from the former, but they are different between each other. Competencies are often mixed up with activities: placing a nasogastric tube, inserting a venous catheter or placing a splint are activities and have no value by themselves, because they only acquire meaning when they are linked to a specific purpose. Competencies consist of the description of the great purposes of the profession, equivalent to the great professional functions that give meaning to the entire professional endeavor. To put the competencies in writing, prototypical practicing medical professionals must be analyzed by means various techniques known as task analysis, ${ }^{6}$ which consist of interviews, expert consensus, shadow studies, walking and talking, critical incident and many others. ${ }^{7}$

However, if we only took current professionals as a model, we would be assuming that the future will be the same as the present, which is an unsustainable statement in a field as dynamic as medicine; a prospective approach must be added in order to determine what changes do we see on the horizon of the profession. If the description is too accurate, the competency becomes rigid and will not allow the changes to be assimilated, and if it is very general, it will not allow the training process to be guided; achieving the right balance is generally required. Due to the above, it is not easy for competencies to be written down. A practical advice for those who are starting in this task is to answer the following questions for each competency: what is the professional going to do (verb)? What is he going to do it for (purpose)? In what context is he going to do it (situation)? How should he do it and what should he avoid (execution criteria)? The latter item is aimed at guiding the evaluation. Competencies will always be open and somewhat imprecise statements to allow change, for this reason they have been described as "fuzzy learning outcomes". ${ }^{8}$

Childs $^{3}$ himself has distinguished two educational approaches: education, thus named because it teaches how to follow instructions; and training, which teaches to continually evolve, develops critical 
thinking and prepares us to adapt to the context and continually advance.

In current medicine we cannot train "laborer doctors", followers of instructions that apply routines in a mechanical, uncritical and insensitive way, and that primarily serve deformed health institutions, and secondarily, people.

The competency-oriented training process is not obtained by simple addition of isolated subject matters that miraculously integrate and produce an adaptive physician; it involves top-down planning, in which the entire curriculum is aligned with final competencies and all subject matters make their contributions. It demands moving from the training of instruction repeaters to the training of "navigators", capable of taking on new challenges and following the continued advance of knowledge. To this end, the dynamic educational process is the most relevant content of the course $^{9}$ It is not only about arriving at the correct result, but also developing correct processes.

\section{Technological innovations}

\section{Ana Carolina Sepúlveda-Vildósola}

Innovation can be restricted to changes that partially affect any of the existing practices (continuous improvement), to refinement and improvement of some element, methodology, strategy, process, means of delivery or procedure (incremental); to applying a new paradigm that significantly changes existing practices (revolutionary) or represents a drastic change in said practice (disruptive).${ }^{10}$ The paradigm of medical care centered on individuals, their treatment and harm rehabilitation has evolved into one where control of the social determinants of disease, prevention and active participation of people in promoting health and treatment of their diseases are increasingly acquiring more relevance. Currently, technological advances in health allow offering personalized, predictive and precision treatments, in contrast to standard treatments of the past.

Similarly, educational paradigms have evolved, from passive pedagogical models and rote learning to active participation of the student, reflection and collective construction of knowledge. Mass education models are now student-centered, allow flexible and personalized curricula, which consider the interests of the learner. Technological innovation (e.g., simulation) has facilitated deliberate practice and acquisition of competencies in a safe way, both for the patient and the student.

Virtually all medical students currently have a smartphone or tablet, which are pocket computers with a variety of functions that favor and facilitate education. ${ }^{11,12}$

Educational practices in the classroom have been facilitated with the introduction of technology such as smart boards and multimedia projectors, which are increasingly compact and have better resolution. Gamification in education (e.g., Kahoot) favors student attention and active participation. The use of social networks in the teaching process favors communication, teamwork and feedback, among others. ${ }^{13}$

Availability of educational materials in digital formats (e.g., compact discs, apps or websites), as well as distance courses, blogs and webinars on platforms in the cyberspace, allows greater access to and individualization of education according to personal interests and favors continuing education, thus reducing costs and geographical barriers. ${ }^{14}$

Simulation has acquired great importance over the past few decades. Recreation of real scenarios, using low or high fidelity technology or virtual reality, allows the student to acquire diverse competencies. Artificial intelligence has been incorporated both to the medical care process and health education; it allows automating tasks, predicting, accompanying and evaluating. ${ }^{15,16}$

Technology should be seen as a means and not as an end of education. It offers innumerable advantages, but it is not without disadvantages. ${ }^{17}$ Table 1 summarizes the pros and cons of technology in health education.

In the past few months, the COVID-19 pandemic has accelerated the use of technology in education. When face-to-face educational activities were suspended, distance classes were initiated through real-time platforms. This was a short-term solution and we must prepare ourselves to potentiate the use of information and communication technologies in the medium and long term, taking advantage of digital transformation. Gamification starts from the premise that "learners learn best when they are also having fun" and takes advantage of human beings' inclination towards competition and entertainment. It involves the development of games that allow the individual to learn from solving problems or challenges and overcoming stages with different degrees of digital complexity, ${ }^{18}$ in order to achieve a disruptive innovation in the process. 
Table 1. Advantages and disadvantages

\begin{tabular}{|c|c|}
\hline Advantages & Disadvantages \\
\hline $\begin{array}{l}\text { - Acceptability and frequency } \\
\text { of use }\end{array}$ & $\begin{array}{l}\text { - Time and cost of materials and/ } \\
\text { or equipment acquisition }\end{array}$ \\
\hline $\begin{array}{l}\text { - Favors active and } \\
\text { collaborative learning, } \\
\text { collaboration, immersion } \\
\text { into contents, interaction, } \\
\text { commitment, construction } \\
\text { of experiences, self-efficacy } \\
\text { and socially contextualized } \\
\text { learning }\end{array}$ & $\begin{array}{l}\text { - Variable quality. It must } \\
\text { integrate medical, educational } \\
\text { and technological components }\end{array}$ \\
\hline $\begin{array}{l}\text { - Favors access to and self- } \\
\text { management of learning } \\
\text { (life-long-learning) }\end{array}$ & - Generational barrier \\
\hline $\begin{array}{l}\text { - Facilitates the connection } \\
\text { between formal and informal } \\
\text { learning } \\
\text { - Safe environments (patient } \\
\text { and student) }\end{array}$ & $\begin{array}{l}\text { - Resistance to change/ } \\
\text { preconceived ideas }\end{array}$ \\
\hline $\begin{array}{l}\text { - Personalized, global } \\
\text { education } \\
\text { - Recreates infrequent } \\
\text { situations }\end{array}$ & $\begin{array}{l}\text { - Lack of motivation } \\
\text { - Requires training and } \\
\text { technological skills }\end{array}$ \\
\hline $\begin{array}{l}\text { - Multi-platform and can be } \\
\text { used to turn leisure time into } \\
\text { productive time } \\
\text { - Scalable experiences } \\
\text { - It can be repeated until } \\
\text { competency is achieved }\end{array}$ & $\begin{array}{l}\text { - Creativity for its use as an } \\
\text { educational resource } \\
\text { - Non-professional use of the } \\
\text { resource }\end{array}$ \\
\hline $\begin{array}{l}\text { - Favors healthy competition } \\
\text { between students and } \\
\text { transfer to real situations } \\
\text { - Greater satisfaction, } \\
\text { enjoyable learning, greater } \\
\text { motivation; in the end, a } \\
\text { feeling of gain } \\
\text { - Allows having real-time } \\
\text { information, at patient } \\
\text { bedside } \\
\text { - Allows keeping individualized } \\
\text { history of advances }\end{array}$ & $\begin{array}{l}\text { - Available resources } \\
\text { - Institutional support } \\
\text { - Teaching load increase } \\
\text { - Difficult student objective } \\
\text { evaluation } \\
\text { - Privacy } \\
\text { - Intellectual property of materials } \\
\text { - Variability in student } \\
\text { participation }\end{array}$ \\
\hline
\end{tabular}

\section{Curricular innovation}

\section{María Esther Urrutia-Aguilar}

The concept of innovation is related to the creation of something unknown, to the perception of that which is created as something new and to the assimilation of that something as novel. ${ }^{19}$ According to Elmore, ${ }^{20}$ in educational innovation we can distinguish between structural changes, which affect the entire educational system, or those that affect the configuration of the different levels; curricular changes, related to design and development; changes in curricular materials, with new teaching approaches; professional changes related to the training, selection and professional development of teachers; and political and social changes, which affect the distribution of power in education and the relationship of social agents with school education.

This manuscript will only refer to the curricular innovation cited by Beltrán, ${ }^{21}$ who considers that the curriculum is not an object, but a process that should include teachers' opinions. Elliott ${ }^{22}$ points out that the faculty is an agent of change in educational situations.

Since last century, there have been three reforms in medical education: the first one early in the $20^{\text {th }}$ century, in which study plans were structured based on science; the second one, in the middle of the same century, which introduced educational innovations such as problem-based learning and evidence-based medicine; the third reform is currently underway, and it is based on improving health systems performance by adapting basic professional competencies to specific contexts.

At the beginning of last century, medical training was considered in two stages: the first one focused on the study of basic sciences, and the second, on clinical practice in hospitals. In the middle of that century, a stage of questionings about the structure of the curricula, their curricular rigidity, the focus centered on teaching and the lack of a comprehensive vision of the patient at its biopsychosocial dimension was initiated. ${ }^{23}$ In addition, educational policies were marked by globalization, international trade and collaboration treaties, a search for certification and homologation of programs and professions, and by the definition of national and international standards. ${ }^{24}$

Towards the middle of last century, teaching students to use the best available scientific evidence for decision-making, incorporation of evidence-based medicine and problem-based learning were introduced as curricular innovations. In addition, leadership theories and biomedical informatics were also included, with the latter being aimed at developing physicians' abilities for handling information. ${ }^{25}$

Currently, most schools are entirely focused on first-generation education, with traditional and stagnant curricula and teaching methods, with inability or even resistance to change, which does not help the training of the doctors that are required, owing to the prevalence of fragmented, obsolete and static curricula. ${ }^{26}$ Students graduate with mismatches in 
competencies for solving the needs of patients and the population, with poor training for teamwork and a tendency to act in isolation. Some countries have incorporated second-generation reforms and a few are moving to the third generation.

Currently, there is a vertiginous development of technologies such as robotics, big data and artificial intelligence; added to this are the social changes resulting from globalization and migration, appearance of new diseases, new infectious, environmental and behavioral risks, changes in demography, and transdisciplinary contributions that have replaced the disciplinary ones, in addition to the fact that patients are more informed today.

The benefits of all these challenges should be oriented towards better medical care, towards promoting inter-professional and trans-professional education; for this, it is necessary to make use of digital resources and a more humanistic medicine. The goal should be the learning of students for retrieving, selecting, evaluating and prioritizing information, developing critical reasoning and acquiring ethical behaviors, but, above all, for integrating themselves as members of receptive and globally connected teams.

Another important aspect to consider is the explosive increase in the volume of information and easy access to it, which is why the next generation of students needs to develop the ability to discriminate large amounts of information and extract and synthesize the knowledge that is necessary for clinical decisions. ${ }^{27}$

\section{Curricular innovation, part II}

\section{José Ángel Córdova Villalobos}

In 2013, the American Medical Association proposed a pillar of medical education called Health System Sciences, which includes, among other topics:

- Patient safety: an essential issue, the importance of which has been strengthened as a result of reports related to medical errors. Consequently, movements such as Patient Safety, in more than 40 countries, have designed 16 apps that remind of medical actions for preventing accidents or inappropriate evolution.

- Health care quality improvement: seeking access to health for all people for the simple fact of being humans. But this prerogative would be incomplete if access is not complemented with quality of health care, for which not only technically trained personnel is required, but health care providers with an attitude of service, as well as health facilities, equipment and the necessary supplies.

- Evidence-based medicine: this constitutes the greatest scientific support in order for the health professional to achieve the best results for patients.

- Health services value: financial decision-makers should understand that health "is not an expense, but an investment", and that if there is not a robust support in terms of facilities, materials, equipment and medication, health personnel vocation, dedication, knowledge and attitudes are not enough for good results to be obtained.

- Interdisciplinary work: currently, health teams are not comprised only by doctors (general practitioners or specialists), but the work of nurses, nutritionists, chemists, rehabilitators, dentists, psychologists, social workers, biomedical engineers and sanitarians is equally important.

- Health care coordination: the distribution and compliance with the functions of each one of the members of the health team is essential; "nobody is more than anybody, everybody is important".

- Resource management: most medical schools do not teach how and with whom to manage resources for the proper functioning of the system, institution or unit; these aspects are rather the field of a specialty, since the doctor must know about planning, administration and management of resources in order to be prepared at any time for occupying a managerial position.

- Population management: both in primary care medicine and in public health management, it is very important in order for most preventive and curative programs to be implemented.

- Biomedical informatics: training in computer knowledge is essential since primary, secondary and high school education, and should be the basis for facilitating permanent search for information by the future doctor in order for his knowledge to be increased and, of course, for solving problems.

- Leadership: not only in medicine but in any profession or job and in daily life it is essential to learn to be a leader or to develop this skill in order to motivate changes, accelerate advances and generate models.

- Financing: generation of awareness that health is an investment, to fulfill the second most important 
human right after the right to life, based on good planning and proper use of resources.

- Health care reform: we have experienced energy, educational, tax reforms, etc.; however, a health care reform has not taken place, neither has it taken place in services for strengthening primary care, or in the training of human resources, since curricula in many institutions are focused on training graduates for being selected to continue with a specialty, rather than with the vision of first training high quality general practitioners. It is necessary to work at previous levels (high school or secondary school) in order to accustom students to more coordinated teamwork at the community level, so that, from there, they recognize, value and work on education, participation and leadership; so that, when they arrive to college they get used to teamwork, to respect the value of each one of their schoolmates, to design projects and carry them out in the most needy communities, with support of their teachers and participation of specialists at primary care centers.

Inter-professional work is also required, between different elements of the health system and with other people from different professions, working as a team.

Reconsideration of the new curriculum should take into account the educational system, health system requirements in accordance with the reform, the demand for certain types of health personnel (primary care doctors), the characteristics and needs of the population and the labor market. In addition, it should be a dynamic curriculum in which values, roles, communication and teamwork are taken into account, and whereby the student gradually experiences active learning.

In summary:

- An intense and sustained dialogue is required between the universities that train human health resources and the health sector, which should constitute a critical reflection that allows creating the bases for professional development and a dynamic, sustainable and profound change.

- At each step, the risks and opportunities each curricular innovation entails should be investigated.

- It will be necessary for the leading role of teachers in the curricular development processes to be rescued, since innovations raise controversies because they question beliefs about teaching, learning and evaluation, due to a resistance to change.
- Focusing on the role of the physician as an educator, incorporating administrative and managerial skills, is required, as well as adding a research axis that trains the student in the handling of information, information and communication technologies, medical informatics and scientific methodology, without marginalizing the ethical and humanitarian components.

- Student participation will be fundamental in the enrichment through life and work experiences, as well as in the evaluation of innovations, within a flexible and dynamic curriculum that will always seek to be better.

\section{Evaluation innovation}

\section{Joaquín J. López Bárcena}

Some proposals allow identifying changes that generate a new paradigm that impacts on existing practices (revolutionary), or others that improve some components of educational process (incremental), or changes that are reproduced from other models and that are barely relevant (continuous improvement). ${ }^{28}$

If evaluation is understood as a process that allows obtaining information for making decisions, it is clear that it cannot be carried out in isolation and that it is applicable to all components of an educational program. Thus, to evaluate, it is necessary to answer the questions what? what for? and how? Innovations are linked to those that are incorporated to the educational approach. ${ }^{29,30}$

Innovations can occur in curricular design, in the educational method and in the instructional modality. Since Flexner, in 1910, there was an inertia, until the 1960s, when some uniformity was found about what had to be evaluated: objectives!, with a practically universal level of impact. The most widely used instruments were structured written tests, with a predominance of questionnaires with multiple-choice questions, very useful for large groups, but limited to a rote and random exercise. This prevails to this day.

The next innovation occurred at the beginning of this century, with the appearance of competency-based education, ${ }^{31}$ understood as a set of domains (knowledge) that are simultaneously and progressively learned. They include knowledge, skills and abilities, behavior, coexistence and teamwork, self-regulated and autonomous learning, as well as creativity and entrepreneurship. 
In recent years, another educational novelty has emerged, which complements competencies: "reliable professional activities" (APROC - actividades profesionales confiables), a Latin version of the entrustable professional activities (EPA), generated in the Netherlands and that their evaluation has required the creation of digital apps for mobile devices, which allow the teacher performing it during daily clinical

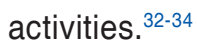

All this implies that the evaluation process has to be multifaceted, preserving validity and reliability. To date, we continue with the competencies and with improvements of new evaluation instruments, which also have to be in accordance with educational method and instructional modalities' variants. This means that several evaluation instruments have to be used for a single competency. Hence, evaluation innovative changes have consisted of modifications to multiple-choice questionnaires and checklists, use of rubrics, use of portfolios, simulators, and, with all their splendor, information and communication technology (ICT) resources, with virtual reality and augmented reality, among others, as well as, although still at initial stages, robotics and telemedicine..$^{35-37}$

In the 1980s, an innovative change that shook methodology in medical education was introduced. Until then, the main figures in the educational process were the teacher and teaching. The former, as a role model, although the dogmatic, autocratic, protagonist, self-indulgent teacher, refractory to any questioning or evaluation of his teaching performance, prevailed. The change has been drastic: the student and learning are now prioritized. The teacher is placed in the background, as an advisor, guide or facilitator, and is subject to constant evaluations by students, education authorities and peers. Teaching was rote and encyclopedic; now it is tried for learning to be significant, to be understood, to be able to be explained and for metacognition to exist. Moreover, current teaching promotes that students learn how to learn, that they develops skills for achieving autonomy and being able to regulate what they need to learn; today, teaching occupies its rightful place: being the essence of the educational process and the reason for the teacher to exist.

In parallel, penetration of ICT and its variants, such as information, communication, knowledge and digital learning techniques (ICKDLT), has favored distance education. Initially used for continuing education and training, its use was followed by formal school education and, currently, as we have recently experienced due to the confinement forced by the pandemic, it has replaced face-to-face education at all its levels. Although it is true that this should be temporary, there are reasons to believe that there will be aspects of learning that will continue with this modality, owing to the advantages it offers.

Although in medical education distance education is still not applicable to several elements of clinical learning, educational innovations have occurred with the use of simulators of different levels of complexity. ${ }^{38,39}$ To evaluate these changes, it is necessary being updated on the use of these innovative educational tools, given that the evaluation mechanisms will have to be designed with them in order for the obtained results to be complemented. Multiple-choice questionnaires should be modified in order for thinking to be required for answering in order for the clinical reasoning process to be used. ${ }^{40}$ Checklists should be more flexible and be complemented by rubrics. Graphic representations (infographics, concept maps, flowcharts, diagrams) can be used, which allow to express the understanding of a clinical situation and its handling, which simultaneously allows evaluating teamwork, communication, and the ability to obtain and select information, creativity in expression and presentation. In addition, there is the resource of using videos to demonstrate clinical and surgical procedures with simulators, as well as clinical skills for patient interviewing in different circumstances and behavior with peers, superiors and subordinates.

The use of several evaluation instruments and at different moments of the training process requires an evolutionary record of the results obtained at each one, which favors reflective self-evaluation and comprehensive assessment of learning and, on the other hand, constant creation of tools and strategies that allow consistency of what is to be evaluated and how to do it. ${ }^{41,42}$

The innovation that has had the biggest impact is objective structured clinical examination (OSCE), which, in spite of having been introduced nearly three decades ago, has evolved. It has a versatility that allows simultaneous evaluation of several components of a competency, such as knowledge assimilation, application, human communication, technical ability and skills, teamwork, patient care, handling of information and behavioral elements in the doctor-patient relationship. It requires a variety of clinical scenarios, various evaluation instruments, use of technology, efficient time management, with the highest possible objectivity. Recording the performance at 
each station facilitates reflective feedback, which is essential in any training process; in reality, more than an instrument, it is a format that brings together several evaluation instruments. One drawback is its high cost, especially if it incorporates standardized simulated patients. ${ }^{43}$

Incorporation of new educational technologies implies an innovative design of evaluation instruments with the same technologies. ${ }^{44,45}$

\section{Emerging innovations}

\section{Melchor Sánchez-Mendiola}

The only way of discovering the limits of the possible is to venture a little way past them into the impossible

ARTHUR C. CLARKE

The pandemic caused by the SAR-CoV-2 virus has generated an unprecedented impact on higher education globally, causing a true cataclysm. This has made for international organizations dedicated to educational policies, such as UNESCO, to establish a series of relevant recommendations for medical schools and faculties. We must anticipate a long-term suspension, focus efforts on trying to ensure training continuity and equity, shift the emphasis of evaluation towards educational evaluation for learning, generate support mechanisms for disadvantaged students, document the changes that are introduced and their impacts, learn from our mistakes and escalate digitization, hybridization and ubiquitous learning, as well as to make a deep reflection on the renewal of our educational models. "The million-dollar question is whether, assuming there is continuity of teaching activities, students will be able to achieve the learning objectives designed for the course", ${ }^{46}$ which leads to explore innovative teaching, learning and assessment mechanisms in health-related professions students, since we have to recognize that, before the pandemic, the educational situation in our health and education system had, to put it mildly, several areas of opportunity.

The pandemic forced an abrupt transition to distance education, a process that affected the programmed education of all medical and nursing students, by closing universities due to home confinement, withdrawing students from clinical areas and transforming usual teaching in the health system into a scenario primarily dedicated to the care of patients with COVID-19. Sudden migration to the use of distance education left teachers teaching skills in a tight spot and strongly complicated the already broad administrative challenges of health sciences faculties and schools, since in addition to migrating to a modality we were not used to, we had to juggle with curricula and evaluations to try to timely comply with the plans and programs scheduled for the school year.

It is important having clear that the education we experienced in the months that followed March 2020 was not "online education" in the literal sense, but "emergency remote education", which is not the same. ${ }^{47}$ In contrast to the educational experiences that were originally planned to be online, emergency remote education is a temporary change to an alternative instructional modality, owing to the crisis caused by the pandemic. It implies the use of entirely remote solutions, which would be taught as face-toface or hybrid courses, and which are supposed to return to their original modality when the emergency ceases. The importance of this difference lies in the fact that we must be clear that the response to the emergency had a lot of improvisation and non-ideal strategies, unlike to what quality online education implies, i.e., online activities planned in advance and pedagogically solid, in professionally designed virtual learning environments and with adequate teaching training for using modern technologies for distance teaching and evaluation.

Although the educational emergency was efficiently responded to through an enormous effort, that which was provided to the students is far from being ideal, and several gaps were generated in the teaching of clinical, psychomotor and field practice skills, which eventually should be remedied. This implies that in the months and years to come we must appropriately incorporate the various modalities and models of online, face-to-face and mixed/hybrid education, with teacher training strategies and curricular development that use good educational practices. For this, it is necessary to rethink our study plans and programs, teaching methods and learning evaluation, as well as to collaborate with colleagues from various schools and faculties in order to develop educational strategies that respond to the enormous challenge we are faced with. ${ }^{48}$

It is necessary to reflect that education in health-related professions has an impact in the long term, and that its results in the clinical care of patients and populations are thus not easily visible in the short term; therefore, without neglecting what is urgent, 
worrying and taking care of what is important in the medium and long term will be necessary. It is amazing how quickly teachers and students migrate to online educational experiences; schools and faculties that have simulation centers increased their activities, and the importance of virtual simulation and the development of "extended reality" models have become visible. The extensive discussions about the roles of students in the health system have generated passionate and heated debates, with strong ethical and professionalism questionings from various sectors of society. In the words of Kevin Eva, editor of the Medical Education journal, we are living "strange days". 49

One of the collateral adverse effects of living an emergency remote education was that several teachers developed what some authors call "covido-pedago-phobia", i.e., rejection of this educational modality, since being their first experience with distance education within this so difficult and unpleasant context, it is natural that they do not wish to continue with this type of teaching in the long term. ${ }^{50}$ It is important for education professionals at universities, accompanied by personnel expert in online education and information and communication technologies, to intensely participate in teacher training activities in order to train teachers in these tools and design educational activities that pick up the best of both worlds, the physical face-to-face and the digital at distance world. We must get used to live with technology not only in daily life and medical practice, but also in teaching activities and learn from our mistakes as we go. Online education was "put away", in that inappropriate social perception that it is something of lower quality or only for people who cannot attend face-to-face activities; now it is in front-row and at the center of the stage of educational world. It is essential for the best educational evidence published on the subject to be used, to generate original knowledge in local contexts and advance in the development of resources and activities that manage to generate enthusiasm in teachers and students.

Activities that we thought were impossible, both clinically and educationally, partly due to perception barriers, are being carried out. In the past few months, we have had many distance education sessions with our students and have participated in countless meetings, sessions, webinars and other activities in which previously we used a lot of time to move, find a place to park and other logistically complicated issues; now we are used to get around in a fairly fluid way between one virtual space and another, including international events and discussions with colleagues in other parts of the world. Telemedicine and telehealth are also being recognized as indispensable elements in the health system, and the role of biomedical informatics in the training of doctors and specialists, as well as in clinical practice, is recovering important spaces. ${ }^{51}$

There is no absolute international consensus regarding a formal definition of educational innovation, although the following elements are common to most: it is a process, it must generate positive and transformational change, it requires creativity and motivation from the different stakeholders of the educational act. ${ }^{52}$ What is happening globally in the practice and teaching of medicine should motivate us for incorporating innovations in the training of health professionals, such as the use of big data and learning analytics, the flipped classroom, massive online open courses (MOOC), use of gamification, extended reality, and Pecha Kucha, among many others. It is clichéd saying that every crisis is an opportunity and that what doesn't kill you makes you stronger, but in current moment of chronic crisis caused by the pandemic we must honestly say "if not now, then when?".

\section{Conflict of interests}

The authors declare that they have no conflicts of interest.

\section{Funding}

The authors were not sponsored to carry out this article.

\section{References}

1. Freidson E. Profession of medicine. Chicago; III.: The University of Chicago Press; 1988.

2. Montori V. Why we revolt: A patient revolution for careful and kind care. Rochester: The Patient Revolution; 2017.

3. Childs B. Genetic medicine: A logic of disease. Baltimore, MD: Johns Hopkins University Press; 2003.

4. Collins $F$, Varmus $H$. A new initiative on precision medicine. $N$ Engl $J$ Med. 2015;372(9):793-795

5. Berwick D. Eating soup with a fork [Youtube]. XIX National Institute for Healthcare Improvement Forum; 2007. Available at: https://www.youtube. $\mathrm{com} /$ watch? $\mathrm{v}=\mathrm{dT}$ tbq9 $\mathrm{cpH} 3 \mathrm{BQ}$

6. Annett J, Stanton N. Task analysis. London: Taylor \& Francis; 2000

7. Fletcher S. Analysing competence. Sterling, Va.: Kogan Page; 1997.

8. Knigth P. Complexity and curriculum: a process approach to curriculum-making. Teaching in Higher Education. 2001;6(3):369-381.

9. Liebmann R, Costa A. Envisioning process as content. Moorabbin, Vic.: Hawker Brownlow Education; 2005

10. González-Flores P, Luna-de la Luz V. La transformación de la educación médica en el último siglo: innovaciones curriculares y didácticas (parte 1). Invest Educ Med. [Internet]. 2019:8(30):95-109.

11. Morn J, Briscoe G, Peglow S. Current technology in advancing medical education: perspectives for learning and providing care. Acad Psychiatry 2018;42(6):796-799 
12. Chandra A, Nongkynrih B, Gupta SK. Role of smartphone technology in medical education in India. Indian J Community Fam Med 2019;5(2):103-107.

13. Cheston Ch, Flickinger T, Chisolm M. Social media use in medical education: a systematic review. Acad Med. 2013;88(6):893-901.

14. Masters K, Ellaway R. e-Learning in medical education Guide 32 Part 2 : technology, management and design. Med Teach. 2008;30(5):474-489.

15. Mozer MC, Wiseheart M, Novikoff TP. Artificial intelligence to support human instruction. Proc Natl Acad Sci U S A. 2019:116(10):3953-3955.

16. Vidal-Ledo MJ. Madruga-González A., Valdés-Santiago D. Inteligencia artificial en la docencia médica. Educ Med Super. 2019;33(3):e1970 Available at: http://scielo.sld.cu/scielo.php?script=sci_arttext\&pi$\mathrm{d}=\mathrm{S} 0864-21412019000300014$

17. Hassall Ch, Lewis D. Institutional and technological barriers to the use of open educational resources (OERs) in physiology and medical education. Adv Physiol Educ. 2017;41(1):77-81.

18. Gorbanev I, Agudelo-Londoño S, González R, Cortés A, et al. A systematic review of serious games in medical education: quality of evidence and pedagogical strategy. Med Educ Online. 2018;23(1):1438718.

19. Margalef-García L, Arenas M. ¿Qué entendemos por innovación educativa? A próposito del desarrollo curricular. Perspectiva Educacional. 2006;47:13-31

20. Elmore K. Restructuring Schools. The next generation of educational reform. San Francisco: Jossey-Bass; 1990.

21. Beltrán-Llavador F. Las determinaciones y el cambio del currículum. In Angulo F, Blanco. N. Teoría y desarrollo del curriculum. Spain: Aljibe; 1994.

22. Elliott J. The struggle to redefine the relationship between "knowledge" and "action" in the academy: some reflections on action research. Educar. 2004;34:11-26.

23. Bosh OA. De Flexner a Bolonia. Educ Med. 2010;13(4):193-195

24. San Martín V. La formación en competencias: el desafío de la educación superior en Iberoamérica. Rev Iberoamer Educ. 2002;29(1):1-8.

25. González-Flores P, Luna-de la Luz V. La transformación de la educación médica en el último siglo: innovaciones curriculares y didácticas. Invest Educ Med. 2020;9(35).

26. Díaz-Barriga F. Desarrollo del currículo e innovación: modelos e investigación en los noventa. Perfiles Educativos. 2005;27(107).

27. Frenk J, Chen L, Bhutta ZA, Cohen J, Crisp N, Evans T, et al. Health professionals for a new century: transforming education to strengthen health systems in an interdependent world. Lancet. 2010; 376(9756): 1923-58.

28. López C. Heredia Y. Marco de referencia para la evaluación de proyectos de innovación educativa. Guía de aplicación Mexico: Instituto Tecnológico y de Estudios Superiores de Monterrey; 2017.

29. Noila-Domenjó M. La evaluación en educación médica. Principios básicos. Educ Med. 2009:12(4):223-229.

30. Maroto-Marín O. Evaluación de los aprendizajes en escenarios clínicos: ¿qué evaluar y por qué? Rev Educ. 2017;41(1):1-18.

31. Abreu L.F. et al. Perfil por competencias del médico general mexicano. Mexico; AMFEM; 2008

32. Hamui-Sutton A, Durán-Pérez VD, García-Téllez SE, Vives-Varela T, Millán-Hernández M, Gutiérrez-Barreto SE. Avances del Modelo Educativo para Desarrollar Actividades Profesionales Confiables (MEDAPROC). Educ Med.2018;19(5):294-300.

33. Hamui-Sutton A, Vives-Varela T, Durán-Pérez VD, García-Téllez SE Gutiérrez-Barreto S, Millán-Hernández M. Mapeo de una propuesta curricular integral basada en la EPA para UME. MedEdPublish. 2019;8(3):37.

34. Ten Cate O. Entrustability of professional activities and competency-based training. Med Educ. 2005;39(12):1176-7.
35. Schiekirka S, Feufel M.A, Herrmann-Lingen Ch, Raupach T. Evaluation in medical education: a topical review of target parameters, data collection tools and confounding factors. Ger Med Sci. 2015;13:1-19.

36. Gil ER, Claramunt EFI, Yago JMC, Salas J, López Al, Pueyo CB, et al. Primeras experiencias en evaluación de la competencia clínica de los médicos de familia de Catalunya. Atención Primaria. 2001;28(2):105-109.

37. Sociedad Española de Educación Médica. Declaración del Lazareto de Mahón: evaluación de las competencias profesionales en el pregrado. Educación Médica. 2004;7(4):103-105.

38. Salomón-Cruz J, Castillo-Orueta ML, De la Cruz GC. Evaluación en la enseñanza de la Medicina en una institución pública. Perspectivas Docentes. 2015;59:5-12.

39. Aungst TD, Clauson KA, Misra S, Lewis TL, Husain I. How to identify, assess and utilise mobile medical applications in clinical practice. Int $J$ Clin Pract. 2014;68(2):155-162.

40. Boushehri E, Soltani Arabshahi K, Monajemi A. Clinical reasoning assessment through medical expertise theories past, present and future directions. Med J Islam Repub Iran. 2015;29:222.

41. Murillo-Sancho G. El portafolio como instrumento clave para la evaluación en educación superior. Rev Actualidades Investigativas en Educación [Internet]. 2012;1(12): 1-23. Available at: https://revistas.ucr.ac.cr/ index.php/aie/article/view/10266/18138

42. Thiessen N, Fischer MR, Huwndlek S. Assessment methods in medical specialist assessments in the DACH region. Overview, critical examination and recommendations for further development. GMS J Med Educ. 2019;36(6):Doc78.

43. Martínez A, Trejo JA. ¿Cómo realizar un ECOE? Inv Educ Med. 2018;7(28):98-107.

44. Hopkins L, Hampton BS, Abbott JF, Buery-Joyner SD, Craig LB, Dalrymple JL, et al. To the point: medical education, technology, and the miIlennial learner. Am J Obstet Gynecol. 2018;218(2):188-192.

45. De Leeuw R, De Soet A, Vandel Horst S, Walsh K, Westerman M, Scheele F. How we evaluate postgraduate medical e-learning: systematic review. JMIR Med Educ. 2019;5(1):e13128.

46. IESALC, UNESCO. COVID-19 y educación superior: de los efectos inmediatos al día después [Internet]; 2020. Available at: http://www.iesalc. unesco.org/wp-content/uploads/2020/04/COVID-19-060420-ES-2.pdf

47. Hodges C, Moore S, Lockee B, Trust T, Bond A. The difference between emergency remote teaching and online learning. EDUCASE Rev. 2020. Available at: https://er.educause.edu/articles/2020/3/the-difference-between-emergency-remote-teaching-and-online-learning

48. Sánchez-Mendiola M. La educación médica y la pandemia: ¿aislarse o colaborar? Invest Educ Med. 2020;9(35):5-7.

49. Eva KW. Strange days. Med Educ. 2020;54(6):492-493.

50. Eachempati P, Ramnarayan K. Covido-pedago-phobia. Med Educ. 2020;54(8):678-680.

51. Sánchez-Mendiola M, Martínez-Franco A, Rosales-Vega A, et al. Development and implementation of a biomedical informatics course for medical students: challenges of a large-scale blended-learning program. J Am Med Inform Assoc. 2013;20(2):381-387.

52. Sánchez-Mendiola M, Escamilla-de los Santos J, Sánchez-Saldaña M. ¿Qué es la innovación en educación superior? Reflexiones académicas sobre la innovación educativa. In: Sánchez-Mendiola M, Escamilla-de los Santos J, editores. Perspectivas de la innovación educativa en universidades de México: experiencias y reflexiones de la RIE 360. Mexico: Imagia; 2018. pp. 19-41. 